\begin{tabular}{rr} 
çağdaş & Yaratıcı Drama Dergisi 2019, 14(2), 297-308 \\
drama & www.yader.org \\
\hline
\end{tabular}

\title{
Masal Anlatımının İlkokul 4. Sınıf Öğrencilerinin Konuşma Prozodilerine Etkisi
}

\author{
Fatih Çetin Çetinkaya ${ }^{1}$ \\ Muhammet Sönmez ${ }^{2}$
}

\begin{tabular}{|c|c|}
\hline Makale Bilgisi & $\ddot{\mathbf{O} z}$ \\
\hline DOI: 10.21612/yader.2019.017 & Masal anlatımının prozodik konuşma becerisine etkisini inceleyen bu çalışma nicel \\
\hline Makale Geçmişi & şeklinde tasarlanmıştır. Çalışma grubu amaçlı örnekleme yöntemlerinden kolay \\
\hline Geliş tarihi & ulaşılabilir durum örneklemiyle belirlenmiştir. Çalışma grubunu Kocaeli ilinde \\
\hline 10.07.2019 & $\begin{array}{l}\text { bir devlet okulunda öğrenim gören } 42 \text { ilkokul öğrencisi oluşturmaktadır. Veriler } \\
\text { ögrencilerin hikâye kartlarından masal oluşturmaları esnasında ses kaydı alınarak } \\
\text { toplanmış, sonrasında Konuşma Prozodisi ölçeğiyle puanlanarak SPSS programında }\end{array}$ \\
\hline Anahtar Sözcükler & analiz edilmiştir. Uygulama sürecinde deney grubu katılımcılarına 3 farklı masal \\
\hline Masal anlatımı & anlatım tekniği kullanılarak toplam 23 masal anlatılmıştır. Sonuç olarak deney grubu \\
\hline Illkokul ögrencileri & $\begin{array}{l}\text { öğrencilerinin konuşma becerileri ön-test ve son-testleri arasında yüksek düzeyde } \\
\text { anlamlı farklılaşma yaşandiğı görülmüş̧ür. }\end{array}$ \\
\hline Prozodi & \\
\hline \multicolumn{2}{|l|}{ Makale Türü } \\
\hline \multicolumn{2}{|l|}{ Araştırma Makalesi } \\
\hline \multicolumn{2}{|c|}{$\begin{array}{l}\text { The Effect of Fairy Tales on the Prosody of Primary School } 4 \text { th } \\
\text { Grade Students }\end{array}$} \\
\hline Article Info & Abstract \\
\hline DOI: 10.21612/yader.2019.017 & $\begin{array}{l}\text { This study, which examines the effect of the tales of narrative expression on the } \\
\text { prozodic speaking skills, is designed as an experimental design with pre-test and post- }\end{array}$ \\
\hline Article History & test control experimental group. The sample of the study group was determined by the \\
\hline 07.05 .2019 & sampling method which is easily accessible. The study group consisted of 42 primary \\
\hline 10.07.2019 & $\begin{array}{l}\text { school students studying in a public school in Kocaeli. The data were collected by } \\
\text { recording the stories of the students with story cards, and then scoring by the Speech }\end{array}$ \\
\hline Keywords & $\begin{array}{l}\text { Prozodic scale and analyzed in the SPSS program. In the application process, } 23 \\
\text { different fairy tales were used for the experimental group participants. As a result, it }\end{array}$ \\
\hline Storytelling & was seen that there was a high level of significant difference between the pre-test and \\
\hline Prozodi & post-test skills of the experimental group students. \\
\hline \multicolumn{2}{|l|}{ Primary school } \\
\hline \multicolumn{2}{|l|}{ Article Type } \\
\hline \multicolumn{2}{|l|}{ Research paper } \\
\hline
\end{tabular}

1 Doç. Dr., Düzce Üniversitesi Eğitim Fakültesi, Temel Eğitim Bölümü Sınıf Eğitimi ABD, Kocaeli, Türkiye. E-posta: fatihcetincetinkaya@gmail.com. Orcid ID: 0000-0002-9843-6747

2 Öğretmen, Hacı Seyit Taşan İlkokulu, Kocaeli İl Milli Eğitim Müdürlüğü, Kocaeli, Türkiye. E-posta: muhammetsnmz41@gmail.com. Orcid ID: 0000-0001-6516-7635 


\section{Giriş}

Bireyler kendilerini ifade edebilmek, duygu ve düşüncelerini aktarabilmek için temel dil becerilerine ihtiyaç duymaktadır. Bu beceriler ise sırasıyla dinleme, konuşma, okuma ve yazma olarak gelişim gösterir. İlkokul öğrencileri, eğitim hayatlarına dinleme ve konuşma becerilerine sahip olarak başlar. $\mathrm{Bu}$ dönemde öğrencilerden dinleme ve konuşma becerilerini zamanla geliştirmeleri beklenirken aynı zamanda okuma ve yazma becerileri de kazandırılmaya çalışılır.

Dinleme becerisinden sonra kazanılan konuşma becerisi, bireylerin içinde bulunduğu ortamda kazandığı ve hayatı boyunca kullandığı en önemli iletişim aracı olarak karşımıza çıkmaktadır (Keskin, Baştuğ, ve Akyol, 2013). Konuşma, bireylerin kendilerini ifade etmeleri bakımından oldukça önemli olmakla birlikte, okuma-yazma faaliyetlerinin de temelini oluşturmaktadır (Temizyürek, 2007). Akıc1 ve etkili konuşma becerisini geliştiren öğrenciler bilgilerini de geliştirmekte, sözlü veya sözel olmayan iletişim durumlarına etkili olarak katılmaları kolaylaşmakta, bu durum sayesinde ise öğrencilerin dil ve zihinsel becerileri gelişim göstermektedir (Güneş, 2014). Öğretim programlarında konuşma becerisine yer verilse de uygulama aşamasında konuşma becerisi ihmal edilmektedir (Doğan, 2009; Keskin, Baştuğ, ve Akyol, 2013). Ancak araştırmalar okullarda çocuklar için konuşma etkinlikleri düzenlemesi gerektiğini söylemektedir (Akyol, 2012). Konuşma, diğer dil becerileriyle beraber düşünüldüğünde etkileşim içerisinde bir ortam oluşmakta, doğru ve etkili konuşabilmek için dinleme ve okuma becerileriyle elde edilen birikimlerin etkili bir şekilde kullanılması gerektiği görülmektedir (Sağlam ve Doğan, 2013). Etkili ve akıcı konuşabilmek için öğrencilere verilecek konuşma eğitimi, belirli kurallara dayandırılmış ve ezbere dayalı bir sistemle gerçekleştirilememektedir (Kurudayığlu, 2003). Öğrencilere verilecek konuşma eğitimi, öğrencilerin, kolay, rahat ve akıcı konuşmalarını sağlayacak niteliğe sahip olmalıdır (Doğan, 2009). Konuşmacı, mesaj1 alıcıya net bir şekilde aktarabilmek için akıcı bir şekilde konuşmalı, konuşmadaki vurgu, tonlama ve anlam ünitelerine dikkat etmelidir (Keskin, Baştuğ, ve Akyol, 2013). Bu da prozodik konuşma ile sağlanabilmektedir.

Prozodi; vurgu, tonlama, anlam gruplarına uygun olarak ifade etme olarak açıklanmakta olup, konuşma diline ait bir kavramdır (Breznitz, 2006). Kısacası konuşma dilinin müziği olarak açıklanmaktadır (Allington, 1983; Dowhower, 1991; Kuhn, Schwanenflugel, ve Meisinger, 2010; Schreiber, 1980; Schreiber, 1991). Konuşma prozodisi, konunun yansıtılması ve duygusal boyutların aktarılmasında konuşmacıya yardımcı olurken (Nygaard, Herold, ve Namy, 2009), konuşmayı ilgi çekici hâle getirerek konuşmanın heyecansız ve robotik şekilde sürdürülmesinin önüne geçmektedir (Keskin, Baştuğ, ve Akyol, 2013). Bu durum ise konuşma prozodisinin tonal ve ritmik boyutlarıyla sağlanmaktadır (Çetinkaya, Yıldırım, ve Ateş, 2017).

Prozodik konuşmayı desteklemenin yollarından bir de masallardan yararlanmaktır. Karatay’a (2007) göre masallar, kelime dağarcı̆̆ını zenginleştirerek dil öğretiminin temel becerileri olan anlama ve anlatma becerilerinin kazandırılmasına katkı sağlamaktadır. Masallarda bulunan ritmik unsurlar ve tekerlemeler, anlatım esnasında prozodinin tonal ve ritmik unsurlarını ortaya çıkarmayı kolaylaştırarak, dinleme ve konuşma becerilerini eğlenceli hâle getirmektedir. Bu bağlamda konuşma ve dinlemeyi geliştirmek için masallardan yararlanılmalıdır. Ayrıca masal anlatmak masal okumak değildir, masal anlatıcısı kendi yaşantılarından yararlanarak anlatma eylemini gerçekleştirmektedir (Duran ve Öztürk, 2018). Masal anlatımı esnasında prozodik konuşmaya dikkat edilmesi, canlandırmalardan faydalanılması ve doğru sözcüklerin seçilmesi gerekmektedir (Güleryüz, 2006; Yalçın ve Aytaş, 2003). Çünkü bir masalın dinleyici üzerinde etkili olabilmesi için masal, dinleyiciye 
iyi bir şekilde sunulmalıdır (Duran ve Öztürk, 2018). Masal anlatımında çeşitli yöntemlerden yararlanılabilmektedir. Bu yöntemlere düz anlatım, hikâye veya masal kitabından anlatma, hikâye kartı ile anlatma, pazen tahta ve figürle anlatma, kuklalar ile masal anlatma teknikleri örnek olarak gösterilebilir. (Kirişgil Doğan, 2012).

Alanyazın incelendiğinde konuşma becerisi üzerine yapılan çeşitli çalışmalara rastlanmıştır;

Temizyürek (2007) ilköğretim ikinci kademede konuşma becerilerinin geliştirilmesi adlı çalışmasında, konuşma becerilerinin geliştirilmesi için yapılabilecek çalışmalara yer vermiş ve eğitim kurumlarında konuşma eğitimi için yapılan etkinliklerden söz etmiştir. Sonuç olarak konuşma eğitiminin önemi ilköğretim programında aktarılsa da uygulama esnasında yetersiz kaldığını aktarmıştır. Türkçe eğitiminde kullanılacak olan konuşma eğitiminin öğrencilerin akıc1 ve düzgün konuşmasına katkı sağlayacağını belirtmiştir. Temizkan (2009) öğrencilerin konuşma becerisinde akran değerlendirmenin etkisini araştıran çalışmasında Türkçe öğretmeni adaylarıyla çalışılmış, araştırmanın sonunda akran değerlendirmenin öğrencilerin konuşma becerilerine katk1 sağladığ1 sonucuna ulaşılmıştır. Sağlam ve Doğan (2013) 7. sınıf öğrencilerinin hazırlıksız konuşma becerilerini inceleyen çalışmasında öğrencilerin cümle kurmada sıklıkla hata yaptığı, kelime bulmada zorlandıkları, sık sık kelime ve cümle tekrarlarına düştükleri tespit etmiştir. Çalışmanın sonucunda öğrencilerin hazırlıksız konuşma becerilerinin yetersiz yahut kısmen yeterli olduğu aktarılmıştır. Kuru (2013) akıcı konuşmada sorun yaşan 5. sınıf öğrencileriyle yaptığı çalışmada çeşitli etkinlikler kullanarak akıcı konuşmada problem yaşayan öğrencilerin akıcı konuşmalarını geliştirmeyi amaçlamıştır. Araştırmanın sonucunda karikatür üzerinden konuşma, akıcı konuşma, hazırlıklı konuşma gibi çeşitli etkinliklerin yapılmasının akıcı konuşma problemi yaşayan çocukların konuşmalarına olumlu etki yaptığı belirlenmiştir. Keskin ve diğerleri (2013) ilköğretim 4. sınıf öğrencilerinin sesli okuma ve konuşma prozodileri arasındaki ilişkiyi incelemek adına yaptıkları çalışmada, sesli okuma ve konuşma prozodisi arasında pozitif yönlü bir ilişki tespit etmiş aynı zamanda araştırmaya katılan öğrencilerin \%48'inin konuşma prozodilerinin düşük seviyede olduğu ortaya konulmuştur. Kuru ve Güneş (2017) akıcı konuşma problemi yaşayan 4. sınıf öğrencilerinin akıcı konuşma becerilerini geliştirmeyi amaçlayan çalışmalarında akıcı konuşmayı geliştirme etkinlikleri kullanmışlardır. Sonuç olarak etkinlikler sonrasında öğrencilerin konuşma becerilerinin nicelik ve nitelik olarak geliştiği görülmüştür. Çetinkaya ve diğerleri (2017) ilkokul dördüncü sınıf okuduğunu anlama becerilerine konuşma ve okuma prozodilerinin nasıl etki ettiğini araştırmışlardır. Araştırmanın sonucunda konuşma prozodisinin anlama sürecini kolaylaştırdığ ve okuma sürecinde dikkate alınması gerektiği bilgisine ulaşılmıştır. Deringöl (2018) sınıf öğretmeni adaylarının konuşma kaygılarını incelemiş, tarama modelli ile tasarlanan çalışmanın sonucunda sınıf öğretmeni adaylarının konuşma kaygılarının öğretmenlik yapmalarını engelleyecek seviyede olmadığı, konuşma kaygısının cinsiyet değişkenine göre farklılaşmadığı, sınıf düzeyleri arttıkça konuşma kaygısının azaldığı bilgilerine ulaşmıştır. Özden (2018) Türkçe öğretmeni adaylarının hazırlıklı ve hazırlıksız konuşma hakkında geliştirdikleri metaforları inceledikleri çalışmada, Türkçe öğretmeni adaylarının hazırlıklı konuşma yaparken kendilerini hazırlıksız konuşmaya göre daha yeterli gördükleri sonucuna ulaşılmıştır.

Alanyazında konuşma prozodisi ile masalın birlikte ele alındığı araştırmaya rastlanmamıştır ve bu alanda yapılan benzer araştırmaların az sayıda olduğu görülmüş̧ür. Karatay (2007) dil edinimi ve değer öğretiminde masalın önemi ve işlevini ele almış, Şahin (2011) masalların çocuk 
gelişimine etkilerini öğretmen görüşleriyle incelemiş, Illıcak ve Bal (2019) masal terapinin anaokulu öğrencilerinin sosyal iletişim becerileri üzerindeki etkisini araştırmıştır. Akgün (2017) sıfatların öğretiminde masal/hikâye anlatım yönteminin etkisini belirlemeye çalışmış, Şimşek (2004) ilköğretim tarih dersi konularının öğretiminde hikâye anlatım yönteminin etkililiğini incelemiş, Duran ve Öztürk (2018) etkileşimli masal anlatımının ortaokul 5. sınıf öğrencilerinin dinleme becerileri üzerindeki etkisini araştırmış, Çetinkaya, Topçam ve Sönmez (2019) Drama yönteminin sınıf öğretmeni adaylarının masal yazma becerilerine etkisini değerlendirmiştir.

$\mathrm{Bu}$ araştırmanının problemi ise masal anlatımının konuşma prozodisi üzerinde etkili olup olmadığı şeklinde belirlenmiştir. Bu yüzden masal anlatımının öğrencilerin konuşma prozodilerine etkisini belirlemek amaçlanmıştır. Ana problem doğrultusunda aşağıdaki alt problemlere yanıt bulmak hedeflenmiştir:

1. Masal anlatım tekniği deney grubunda bulunan tüm öğrenciler üzerinde aynı etkiyi sağlar mi?

2. Deney ve kontrol grubunda uygulanan farklı teknikler, bu gruplar arasında bir fark oluşturur mu?

3. Kontrol grubuna uygulanan geleneksel yöntemler katılımcıların prozodik konuşma becerilerini etkiler mi?

\section{Yöntem}

\section{Araştırma Modeli}

Masal anlatımının konuşma prozodisine etkisini incelemeyi amaçlayan bu çalışma, nicel araştırma modellerinden ön-test son-test, kontrol deney gruplu yarı deneysel desen olarak tasarlanmıştır. Deneysel desenlerde amaç yapılan uygulamanın sonuca etkisini belirlemeye çalışmaktır (Creswell, 2014). Yarı deneysel desenlerde gruplar rastgele atanmaktadır (Keppel, 1991).

\section{Çalışma Grubu}

Araştırma Kocaeli ilinde bir devlet okulunda öğrenim gören 42 öğrenciyle beraber yürütülmüştür. Araştırmanın deney grubunu 23 öğrenci oluştururken kontrol grubu 19 öğrenciden oluşmuştur. Araştırmanın çalışma grubu amaçlı örneklem yöntemlerinden kolay ulaşılabilir durum örnekleme yöntemi ile belirlenmiştir. Bu yöntemde araştırmacı ulaşılması ekonomik ve kolay olan duruma yönelir (Glesne, 2015).

\section{Veri Toplama Araçları}

Masal anlatımının konuşma prozodisine etkisini inceleyen bu araştırmanın verileri Samuelsson, Scocco ve Nettelbladt'nn (2003) geliştirdiği “Prozodik Değerlendirme İşlemi”ni temel alarak, Keskin ve diğerleri (2013) tarafından oluşturulan 16 maddelik "Prozodik Konuşma Ölçeği" kullanılarak elde edilmiştir. Ölçeğin güvenirliği için hesaplanan Crombach's Alpha değeri .975 bulunmuştur. Buna ek olarak ölçeğin maddelerinin Konuşma Prozodisini uygunluğu 3 ayrı uzmanın görüşleri neticesinde oluşturulmuştur. Aynı zamanda hikâye kartları, resimli çocuk kitapları ve masal kuklalarından da veri toplama aşamasında yararlanılmıştır. Hikâye kartları toplam 60 adet olmakla beraber her birinin üzerinde farklı bir resim bulunmaktadır. Araştırma sürecinde toplam 
15 adet resimli çocuk kitabı kullanılmış, 3 adet masalın anlatımında kuklalardan yararlanılmıştır. Bunlara ek olarak 5 masal da hikâye kartları ile oluşturulup anlatılmıştır. Masal kahramanlarının betimlenmesi amacıyla kullanılan kuklalar; ördek, kral tacı ve kılıcı, cadısüpürgesi olarak seçilip bu kuklalar aracılığıyla masallar anlatılmıştır.

Tablo 1. Anlatılan resimli çocuk kitapları
1. Hafta
Bay Ka Buk ve Ejder, Balıkçı Osman, Koca Roni
2. Hafta
Kayıktaki Çocuk, Yazı Yazan İnekler, Gezegenimizi Yiyip Bitirdiğimizde,
3. Hafta
Annemin Çantası, Cömert Ağaç, Yolculuk,
4. Hafta
Babam Uyumak Bilmiyor, Pezzettino, Ben Sandalye Değilim
5. Hafta
Bir Fikirle Ne Yaparsın, Bu Kitapta Hiç Resim Yok, Arkadaşım Korku

Tablo 1'de uygulama sürecinde anlatılan kitaplar yer almaktadır.

Uygulama esnasında kullanılan resimli çocuk kitapları uzman görüşleri doğrultusunda prozodi unsurlarını içerme kriteri ile belirlenen 30 kitap arasından yine uzman görüşleri alınarak seçilmiş̧ir. Araştırmanın bu kısmını üç farklı uzmandan yardım alınarak yürütülmüştür.

\section{Verilerin Toplanması}

Masal anlatımının konuşma prozodisine etkisini araştıran bu çalışma ön-test son-test, kontrol deney gruplu yarı deneysel desen olarak tasarlanmıştır. Çalışma grubu amaçlı örnekleme yöntemiyle belirlenerek, Kocaeli ilinde araştırmacının görev yaptığ 1 bir okulda öğrenim gören 42 öğrenci olarak belirlenmiştir. Kontrol deney grubu seçkisiz olarak atanmış, deney grubunu 4-C şubesinde öğrenim gören 23 öğrenci, kontrol grubunu 4-D şubesinde öğrenim gören 19 öğrenci oluşturmuştur. Araştırmanın ön test verilerini elde etmek için her bir katılımcıdan toplam 60 farklı karttan oluşan hikâye kartlarından rastgele 6 tanesini seçmesi ve seçilen kartların üzerinde bulunan görsellerden hareketle katılımcılardan masal oluşturup anlatmaları istenmiştir. Her katılımcı tek tek dinlenmiş ve kartlar karıştırılıp sonraki katılımcı için ortam hazırlanmıştır. Katılımcılar masal anlatırken ses kaydı alınmıştır. Alınan ses kayıtları dinlenerek 16 maddeden oluşan "Konuşma Prozodisi Ölçeğiyle" puanlanmıştır. Puanlama aşamasında 2 araştırmacı da yer almış, araştırma güvenirliği için Miles ve Huberman'ın (1994) önerdiği güvenirlik formülü kullanılmıştır. Puanlama işlemi tamamlandıktan sonrasında Mann Whitney U testi kullanılarak gruplar arasında anlamlı bir fark olmadığ tespit edilmiştir. Bu aşamada yapılan istatistiksel uygulamalar çalışmanın denk gruplar arasında gerçekleştirilmesi için önem arz etmektedir. Grupların denk olduğu sonucuna ulaşıldıktan sonra çalışmaya devam edilmiştir.

Uygulama sürecinde kontrol grubuna herhangi bir işlem uygulanmamış, Türkçe dersi faaliyetleri bakanlık tarafından dağıtılan ders kitaplarında yer alan metinler doğrultusunda yürütülmeye devam edilmiştir. Deney grubunda, uygulama sürecinde önce katılımcılardan bildikleri masalları anlatmaları istenmiş, katılımcıların anlattıkları masallardan yola çıkarak masalın unsurları ve özellikleri aktarılıp oturum sonlandırılmıştır. Masalın unsurları hakkında katılımcıların yeterli bilgiye sahip olmaları sağlandıktan sonra masal anlatma aşamasına geçilmiştir. Masal anlatım tekniklerinden 
kukla ile masal anlatma, hikâye kartları ile masal anlatma ve kitaptan masal anlatma teknikleri ile 5 hafta boyunca toplam 23 masal anlatılmıştır. Hikâye kitapları ile masal anlatma işleminde masala başlamadan önce sınıf oturma düzeni masal formatına göre değiştirilmiş ve hikâye kitaplarının masal özelliklerini tam anlamıyla yansıtması amacıyla hikâyenin başına ve sonuna bir masal tekerlemesi eklenmiştir. Sonrasında Ateş’in (2013) "Peritextual konuşmayla hikâyeye başlama" aşamaları temel alınarak masal anlatma işlemene geçilmiştir. Peritextual okuma kitapta yer alan peritextual unsurlardan (resimli kitapların kılıfi, ön ve arka kapakları, ön kapaktan sonra ve arka kapaktan önce yer alan sayfalar, iç kapak, başlık bölümü, yayıncı ve ithaf bilgileri gibi) söz edilerek peritextual okuma gerçekleştirilmiştir. Peritextual okumanın ardından kitaplar masallaştırılarak anlatılmış, öğrencilerin masalı sosyal hayatla bağdaştırıp, hazırlıksı konuşma becerilerini geliştirmek için masal içeriği ile ilgili etkinlikler gerçekleştirilmiştir.

Tablo 2. Anlatılan resimli çocuk kitapları ve gerçekleştirilen etkinlikler

\begin{tabular}{|c|c|}
\hline Kitaplar & Konuşmaya yönelik etkinlikler \\
\hline Bay Ka Buk ve Ejder & $\begin{array}{l}\text { Öğrencilerden, kitapta tekrar edilen hayal kavramına vurgu yapılarak } \\
\text { "Arkama yaslandım ve hayal kurdum benim hayalim...” cümlesiyle başlayıp } \\
\text { hayalleri anlatmaları istenmiştir. }\end{array}$ \\
\hline Balıkçı Osman & $\begin{array}{l}\text { Öğrencilerden, Balıkçı Osman’ın topladı̆̆ı çöpleri nasıl daha etkili } \\
\text { kullanabiliriz sorularına yanıt vermeleri istenmiştir. }\end{array}$ \\
\hline Koca Roni & $\begin{array}{l}\text { Koca Roni kitabında yer alan olaylardan hareketle, normal şartlarda } \\
\text { sığamayacakları kadar küçük bir bölgeye arkadaşlarıyla birlikte sığmaları } \\
\text { beklenmiş, ardından dışarıda kalan öğrencilerden ve arkadaşlarını alana } \\
\text { sığdıramayan öğrencilerden neler hissettiklerini anlatmaları istenmiştir., }\end{array}$ \\
\hline Kayıktaki Çocuk & $\begin{array}{l}\text { "Bir Kayık yolcuğu yapsaydınız Nereye gitmek isterdiniz?” soru sorularak } \\
\text { kitapta tekrar eden cümlelerle birlikte öğrencilerin konuşmaları sağlanmıştır. }\end{array}$ \\
\hline Yazı Yazan İnekler & $\begin{array}{l}\text { Öğrencilerden "Tıkır tıkır mööö" ifadesi ile başlayan ve temel ihtiyaçlarımızı } \\
\text { konu alan konuşma yapmaları istenmiştir. }\end{array}$ \\
\hline $\begin{array}{l}\text { Gezegenimizi Yiyip } \\
\text { Bitirdiğimizde }\end{array}$ & $\begin{array}{l}\text { Öğrencilerden “Gezegenimizi yiyip bitirdiğimizde, mağarada saklanan son } \\
\text { çocuk siz olsaydınız, sorunları çözmek için neler yapardınız?” Sorusuna } \\
\text { cevap vermeleri beklenmiştir. }\end{array}$ \\
\hline Annemin Çantası & $\begin{array}{l}\text { Çanta mı süper anne mi? Sorusundan yola çıkarak öğrencilerden “Anneniz } \\
\text { çok ünlü bir süper kahraman olsaydı neler hissederdiniz?” sorusuna yanıt } \\
\text { vermeleri istenmiştir. }\end{array}$ \\
\hline Cömert Ağaç & $\begin{array}{l}\text { Doğanın fedakâr tavrına karşı insanların tavırları sebepler-sonuçlar şeklinde } \\
\text { grup tartışmaları yapılarak ortaya konulmaya çalışılmıştır. }\end{array}$ \\
\hline Yolculuk & $\begin{array}{l}\text { Öğrencilerden gruplar halinde zorunlu göç ile ilgili canlandırmalar } \\
\text { yapmaları istenmiş, canlandırma sonrasında diğer öğrenciler akranlarının } \\
\text { canlandırmaları üzerine eleştiriler sunmuştur. }\end{array}$ \\
\hline Babam Uyumak Bilmiyor & $\begin{array}{l}\text { Uyku düzenin ve zinde olmanın önemi hakkında öğrencilerden ikna edici } \\
\text { konuşma yapmaları beklenmiştir. }\end{array}$ \\
\hline Pezzettino & $\begin{array}{l}\text { Ben kimin parçasıyım acaba sorusundan yola çıkarak, sınıf içersinde kitapta } \\
\text { geçen olaylar dramatize edilmiş, insanların kendilerini oldukları gibi neden } \\
\text { kabul etmedikleri sorunsa yanıt aranmıştır. }\end{array}$ \\
\hline
\end{tabular}


Tablo 2. Anlatılan resimli çocuk kitapları ve gerçekleştirilen etkinlikler (Devamı)

\begin{tabular}{|c|c|}
\hline Kitaplar & Konuşmaya yönelik etkinlikler \\
\hline Ben Sandalye Değilim & $\begin{array}{l}\text { Kendini ifade edebilme yeteneğinin önemi hakkında öğrencilerin düşünceleri } \\
\text { alınmıştır. }\end{array}$ \\
\hline Bir Fikirle Ne Yaparsin & $\begin{array}{l}\text { "Bir fikirle dünyayı değiştirebilirsin ifadesiyle ne anlatılmak isteniyor? } \\
\text { Sorusuyla öğrencileri konuşmaya sevk edilmiştir. }\end{array}$ \\
\hline Bu Kitapta Hiç Resim Yok & $\begin{array}{l}\text { Öğrencilerden hangi tür kitapları okumayı tercih ettikleri ve kitap seçerken } \\
\text { nelere dikkat ettiklerini açıklamalar istenmiştir. }\end{array}$ \\
\hline Arkadaşım Korku & $\begin{array}{l}\text { Öğrencilerden korkularını açıklamaları istenmiş ve akranları ile birlikte bu } \\
\text { korkularla nasıl mücadele edebileceği üzerine konuşmaları sağlanmıştır. }\end{array}$ \\
\hline
\end{tabular}

Kuklalar ve hikâye kartları ile anlatılan masallar doğaçlama olarak anlatım esnasında tasarlanmış, 5 hafta boyunca haftada bir masal 60 tane hikâye kartının arasından rastgele seçilen 5 kartın üzerindeki görsellerden yararlanılarak kurgulanmıştır. Kuklalardan anlatılan masallarda da aynı yöntem izlenmiş, anlatım esnasında oluşturulan 3 masalın anlatımı kuklalar yardımıyla gerçekleştirilmiştir. Uygulama aşamasında kullanılan masallar da prozodik ögelerin varlığı bu çalışmada kullanılmalarında kriter olarak ele alınmıştır. Bu sayede konuşma prozodisi anlatım esnasında öğrencilere daha kolay hissettirileceği düşünülmüştür. Ayrıca kitapların belirlenme sürecinde 3 farklı uzmandan yardım alınmıştır.

5 hafta süren uygulama aşaması sonrasında katılımcılara ön testte yapılan işlem tekrarlanılmış, her katılımcının tek tek masalını anlatması için ortam hazırlanmış ve hikâye kartları arasından seçilen 6 karttan masal kurgulayıp anlatmaları istenmiştir. Masal anlatımı esnasında ses kaydı alınarak katılımcıların konuşma prozodileri sonrasında Konuşma Prozodisi Ölçeği aracılığıyla puanlanmıştır. Puanlama 2 araştırmacı tarafından gerçekleştirilmiş ve Miles ve Huberman'ın (1994) önerdiği güvenirlik formülü kullanılmıştır. Deney ve kontrol grubu verileri üzerinden gerekli analizler yapılarak araştırma sonlandırılmıştır.

\section{Verilerin Analizi}

Konuşma Prozodisi Ölçeğiyle elde edilen veriler 2 araştırmacı tarafindan dinlenerek puanlandıktan sonra nicel veriler hâline getirilmiştir. Araştırmacılar arasındaki görüş birliği belirlemek için Miles ve Huberman'ın (1994) önerdiği güvenirlik formülü kullanılmıştır. Hesaplama sonucunda araştırmanın güvenirlik değeri \%85 olarak tespit edilmiştir. Bu formüle göre kodlayıcılar aras1 görüş birliği en az \%80 olmalıdır (Miles ve Huberman, 1994;Patton, 2002).

Güvenirlik = Görüş Birliği / (Görüş Birliği + Görüş Ayrılığı)

Analiz aşamasında SPSS programından yardım alınmıştır. Araştırma esnasında anlamlılık değeri 0.05 kabul edilerek verilerin normallik durumlarına göre yapılacak teste karar verilmiştir. Normal dağılım gösteren tekrarlı ölçümlerde Paried Sample T Testi, Normal dağılım göstermeyen tekrarlı ölçümlerde Wilcoxon işaretli sıralar testi kullanılmış, normal dağılmayan bağımsız iki grubun verilerinde ise Mann-Whitney $U$ testi ile analizler gerçekleştirilmiştir. 


\section{Bulgular}

Verilerin bulgular hâline getirilmesinde öncelikle verilerin normallik durumları SPSS programı kullanılarak incelenmiştir. Kontrol grubunun ön-test puanlarının normallik dağılımı 0.404, son test puanlarının normallik dağılımı 0.197 olarak tespit edilmiştir. Kontrol grubunun ön test ve son test puanları $\mathrm{P}>0.05$ olduğu için normal dağıldığı sonucuna ulaşılmıştır. Deney grubu ön test verileri analizler sonucunda 0.024 olarak tespit edilmiş, $\mathrm{P}<0.05$ olması sebebiyle ön test verilerinin normal dağılmadığ 1 , son test verilerinin ise 0.090 olarak $\mathrm{P}>0.05$ normal dağ 1 ldı $\breve{g}_{1}$ sonucuna ulaş1lmıştır.

Tablo 3. Deney ve Kontrol Grubundaki Katılımclları Ön-Test Puanlarına Ait Mann Whitney U Testi Sonuçları

\begin{tabular}{llccccc}
\hline Ön-Test & & $\mathbf{n}$ & $\overline{\mathbf{x}}$ & $\boldsymbol{U}$ & $\boldsymbol{Z}$ & $\mathbf{p}$ \\
\hline Konuşma & Deney & 23 & 15.96 & 208.00 & -.226 & .790 \\
Prozodisi & Kontrol & 19 & 14.32 & & & \\
& Toplam & 42 & 15.21 & & & \\
& & & & & & \\
\hline
\end{tabular}

Tablo 3' de deney ve kontrol grubunun ön test puanlarına ait Mann Whitney U testi sonuçlarına yer verilmiştir. Tablo incelendiğinde deney grubundaki katılımcıların aldıkları puanların ortalaması 15.96, kontrol grubundaki katılımcıların aldıkları puanların ortalaması 14.32 olduğu görülmektedir. Bunlara ek olarak araştırmaya katılan tüm katılımcıların ortalaması ise 15.21 olarak tespit edilmiştir. Ayrıca Mann Witney U Testi sonuçlarına göre deney ve kontrol gruplarının konuşma prozodileri arasında anlamlı bir fark olmadığı görülmektedir $(Z=-226, p>.05)$.

Tablo 4. Kontrol Grubundaki Katılımcıların Ön-Test ve Son Test Puanlarının Paried Sample T testi ile Karşılaştırılması

\begin{tabular}{llcccc}
\hline Kontrol Grubu & & $\mathbf{n}$ & $\overline{\mathbf{x}}$ & $\boldsymbol{s s}$ & $\mathbf{p}$ \\
\hline Konuşma Prozodisi & Ön-Test & 19 & 14.32 & 2.59 & .023 \\
& Son-Test & 19 & 15.79 & & \\
\hline
\end{tabular}

${ }^{*} \mathrm{p}<.05$

Tablo 4'de kontrol grubunun ön-test ve son-test puanlarının bağımlı T Testi ile karşılaştırılması sonucu elde edilen bulgular görülmektedir. Tablo incelendiğinde kontrol grubunun ön-test, son- test verilerinin anlamlı şekilde farklılaştığ görülmektedir $(.023, \mathrm{p}<.05)$.

Tablo 5. Deney Grubundaki Katılımcıların Ön-Test ve Son Test Puanlarının Wilcoxon İşaretli Stralar Testi ile Karşılaştırılması

\begin{tabular}{llccccc}
\hline Son-Test / Ön-Test & & n & Sıra Ort. & Sıra Top. & z & p \\
\hline Konuşma Prozodisi & Negatif Sıra & 2 & 10.00 & 20.00 & $-3,593$ & .000 \\
& Pozitif Sıra & 21 & 12.19 & 256.00 & & \\
& Eşit & - & - & - & & \\
\hline
\end{tabular}

${ }^{*} \mathrm{p}<.05$

Tablo 5' de deney grubunun ön-test ve son-test puanlarından aldıkları puanların Wilcoxon işaretli sıralar testi ile karşılaştırma sonucuna yer verilmiştir. Tablo incelendiğinde deney grubunun öntest son-test puanları arasında oldukça yüksek derecede anlamlı bir farklılaşma olduğu görülmektedir $(.00, \mathrm{p}<.05)$. 
Tablo 6. Deney ve Kontrol Grubundaki Katılımcılarn Son-Test Puanlarına Ait Mann Whitney U Testi Sonuçları

\begin{tabular}{llccccc}
\hline Son-Test & & $\mathbf{n}$ & $\overline{\mathbf{x}}$ & $\boldsymbol{U}$ & $\boldsymbol{Z}$ & $\mathbf{p}$ \\
\hline Konuşma & Deney & 23 & 24.61 & 103.00 & -2.925 & .003 \\
Prozodisi & Kontrol & 19 & 15.79 & & & \\
& Toplam & 42 & 20.62 & & & \\
\hline
\end{tabular}

${ }^{*} \mathrm{p}<.05$

Tablo 6'da deney ve kontrol grubuna ait son-test puanlarının Mann Whitney U testi analiz sonuçlarına yer verilmiştir. Tablo incelendiğinde Deney grubunda alınan puanların ortalamasının 24.61, kontrol grubunda alınan puanların ortalamasının 15.79 olduğu görülmektedir. Toplam puanların ortalaması ise 20.62 olduğu sonucuna ulaşılmıştır. Bu duruma göre deney grubunda alınan puanların ortalamasının kontrol grubuna göre yüksek olduğu söylenebilir. Ayrıca iki grubun son test verileri arasında yüksek derecede bir anlamlı fark olduğu görülmektedir ( $Z=-2925, \mathrm{p}<.05)$.

\section{Tartışma, Sonuç ve Öneriler}

Masalların dil edinimi ve değer öğretimi, sosyal iletişim becerileri, çocuk gelişimi gibi çeşitli alanlarda önemli etkileri olduğu birçok araştırma tarafından ortaya konulmuştur (Akgün, 2017; Duran ve Öztürk, 2018; Illıcak ve Bal, 2019; Karatay, 2007; Kirişgil Doğan, 2012; Şahin, 2011; Şimşek, 2004) . Karatay (2007), evrensel değerlerin öğretiminde ve dil becerilerinin gelişiminde masalların önemli yeri olduğunu aktarmaktadır. Bu çalışmada da dil becerilerinden biri olan konuşma becerisinin gelişimimi masal anlatımıyla yöntemiyle incelenmiş, araştırma sonucunda Karatay’ın (2007) aktardığı sonuca bezer bir şekilde masal dinleyen çocukların konuşma becerileri önemli ölçüde gelişim gösterdiği görüşmüştür. Masalların hayal gücünü kullanmaya olanak tanıması, iyi kötü kavramlarının bir arada kullanılmasıyla çeşitli zıtlıkları bir araya getirmesi, masal dinleyen öğrencileri farklı yaşantılarla karşı karşıya bırakarak öğrencilerin kelime hazinelerini etkilemektedir. $\mathrm{Bu}$ bağlamda kelime hazinesi gelişen çocukların konuşma becerileri de önemli şekilde ilerleme göstermektedir. Duran ve Öztürk (2018) benzer bir çalışmada etkileşimli masal anlatımının ilkokul öğrencilerinin dinleme becerileri üzerindeki etkisini incelmiş, sonuç olarak etkileşimli masal dinleyen çocukların, geleneksel yöntemle masal dinleyen çocuklara göre dinleme becerilerinin anlamlı şekilde farklılaştı̆̆ını aktarmıştır. Dil becerileri ele alındığında dinleme becerisinin kazanılmasından sonra konuşma becerisi gelişim göstermeye başlamaktadır. Duran ve Öztürk'ün (2018) çalışmasında ulaşılan sonuçlar bu çalışmanın sonuçlarını desteklediği söylenebilir. Dinleme becerisi yüksek olan öğrenciler konuşma becerileri de bundan olumlu bir şekilde etkilenecektir. Masal anlatımı da hem dinlemeyi hem de konuşmayı etkileyen önemli bir yöntemdir. Keskin ve diğerleri (2013) sesli okuma ve konuşma prozodisi arasındaki ilişkiyi inceleyen çalışmaları sonucunda, sesli okuma ve konuşma prozodisi arasında orta düzeyde pozitif yönlü bir ilişki tespit etmiştir. Çetinkaya ve diğerleri (2017) ise okuduğunu anlama becerileri üzerinde konuşma prozodisinin de etkili olduğunu belirlemiştir. Bu sonuçlardan yola çıkarak masal anlatımının dinleme ve konuşma becerilerine doğrudan, okuma ve anlama becerilerine ise dolaylı olarak katkı sağladığı söylenebilir.

Illıcak ve Bal (2019) temel konuşma becerilerini temel alarak yaptıkları çalışmada, okul öncesi öğrencilerinin sosyal iletişim becerilerine masal terapinin etkisini incelemiştir. Araştırma 
sonucundan masal terapinin katılımcıların sosyal iletişim becerileri üzerinde önemli ölçüde etkiliği olduğu tespit edilmiştir. Masal dinlemenin prozodik konuşmayı desteklemesi, prozodi içerisinde yer alan anlam üniteleri, vurgu-ses-tonlama unsuru gibi konuşma içerisindeki anlamı aktarmakta önem arz eden araçlar sosyal iletişim açısından oldukça önemlidir. Masal anlatım yöntemiyle öğrencilerin prozdik konuşmaları sağlanabilir bununla birlikte sosyal iletişim becerileri yükseltilebilir.

Masal anlatımının konuşma prozodisinde bu denli etkili olmasının bir sebebi de masal anlatım yönteminin öğrencilerin kelime hazinelerini desteklemesidir. Kelime hazinesi desteklenen öğrenciler bu durumu konuşmalarına yansıtarak prozodik bir şekilde konuşa bilmektedir. Akgün (2017) sıfatların öğretiminde masal anlatım yönteminin etkisini incelemiş, araştırma sonunda masal anlatımının Türkçe derslerinde yalnızca dinleme ve konuşma becerileri üzerinde etkili olmadığı bu becerilerin yanı sıra öğrencilerin sözcük dağarcığı olumlu yönde etkilediğini belirlemiştir.

Sonuç olarak öğrencilerin temel dil becerilerinin birçoğu ve prozodik konuşma becerileri masal anlatım teknikleri kullanılarak geliştirilebilir.

Araştırma sonrasında öğretmenlerin Türkçe dersleri içerisinde öğrencilere masal anlatmaları, eğitim fakülteleri bünyesinde bulunan Çocuk Edebiyatı derslerinde masal anlatım tekniklerinin öğretmen adaylarına etkili bir şekilde aktarılması, sınıf öğretmenlerinin masallar aracılığıyla ders içi etkinlikleri zenginleştirmeleri, öğrencilere masal anlatım teknikleriyle masallar anlattırarak konuşma prozodilerini geliştirecek uygulamalar yapmaları önerilebilir. Aynı zamanda masal anlatım yönteminin öğrencilerin kelime hazinelerine etkisini ölçmeyi hedefleyen araştırmalar da yapılabilir. 


\section{Kaynakça}

Akgün, N. (2017). Sıfatların öğretiminde masal/hikâye anlatım yönteminin etkisi. International Journal of Languages' Education and Teaching, 5(3), 662-671.

Akyol, H. (2012). Programa uygun Türkçe ögretim yöntemleri. Ankara: Pegem Akademi.

Allington, R. L. (1983). Fluency: The neglected reading goal. The Reading Teacher, (36), 556-561.

Ateş, S. (2013). İlkokulda peritextual okumadan metinler arası okumaya resimli hikâye kitabı okuma süreci. International Journal of Human Sciences, 10(1), 1567-1585.

Breznitz, Z. (2006). Fluency in reading: Synchronization of processes. Mahwah, NJ, US: Lawrence Erlbaum Associates Publishers.

Creswell, J. W. (2014). Araşstırma deseni (4.bs.). Ankara: Eğiten Kitap.

Çetinkaya, F. Ç., Topçam, A. B. ve Sönmez, M. (2019). Drama yönteminin sınıf öğretmeni adaylarının masal yazma becerilerine etkisi. Ana Dili Ë̆itimi Dergisi, 7(2), 337-352.

Çetinkaya, F. Ç., Yıldırım, K. ve Ateş, S. (2017). İlkokul dördüncü sınıf öğrencilerinin okuduğunu anlama becerilerinin üzerinde konuşma ve okuma prozodisinin etkisi. Türkiye Sosyal Araştırmalar Dergisi, 451-464.

Deringöl, Y. (2018). Sınıf öğretmeni adaylarının konuşma kaygıları. MCBÜ Sosyal Bilimler Dergisi, 16(3), 23-35.

Doğan, Y. (2009). Konuşma becerisinin geliştirilmesine yönelik etkinlik örnekleri. Türk Eğitim Bilimleri Dergisi, 7(1), 185-204.

Dowhower, S. L. (1991). Speaking of prosody: Fluency's unattended bedfellow. Theory into Practice, (30), 165-175.

Duran, E. ve Öztürk, E. (2018). Etkileşimli masal anlatım tekniğinin ortaokul 5. sınıf öğrencilerinin dinleme becerilerine etkisi. Avrasya Dil Eğitimi ve Araştırmaları Dergisi, 2(2), 85-103.

Glesne, C. (2015). Becoming qualitative researchers: An introduction (5.bs.). Boston: Pearson Education.

Güleryüz, H. (2006). Yaratıcı çocuk edebiyatı. Ankara: Pegem A Yayıncılık.

Güneş, F. (2014). Konuşma öğretimi yaklaşım ve modelleri. Bartın Üniversitesi Eğitim Fakültesi Dergisi, 3(1), $1-27$.

Illıcak, N. G. ve Bal, F. (2019). Masal terapinin anaokulu öğrencilerinin sosyal iletişim becerileri üzerindeki etkisinin incelenmesi. Avrasya Sosyal ve Ekonomi Araştırmaları Dergisi, 6(3), 517-533.

Karatay, H. (2007). Dil edinimi ve değer öğretimi sürecinde masalın önemi ve işlevi. Türk Egitim Bilimleri Dergisi, 5(3), 463-475.

Keppel, G. (1991). Design and analysis: A researcher's handbook. NJ: Prentice Hall: Englewood Cliffs.

Keskin, H. K., Baştuğ, M. ve Akyol, H. (2013). Sesli okuma ve konuşma prozodisi: İlişkisel bir çalışma. Mersin Üniversitesi Eğitim Fakültesi Dergisi, 9(2), 168-180.

Kirişgil Doğan, F. (2012). Okul öncesi dönemde masal öğretiminde insancıl (hümanist) ve teknolojik (e-kitap) yöntemlerinin karşılaştırılması. (Yayımlanmamış Yüksek Lisans Tezi). Necmettin Erbakan Üniversitesi Eğitim Bilimleri Enstitüsü Konya.

Kuhn, M. R., Schwanenflugel, P. J., ve Meisinger, E. B. (2010). Aligning theory and assessment of reading fluency: Automaticity, prosody, and definitions of fluency. Reading Research Quarterly, 42(2), 230-251.

Kuru, O. (2013). Akıcı konuşma problemi yaşayan ilköğretim 5. sınıf öğrencilerinin konuşma becerisine etkisi. Uluslararası Türk Eğitim Bilimleri Dergisi(1), 88-105.

Kuru, O. ve Güneş, F. (2017). Akıcı konuşma problemi yaşayan ilkokul 4. sınıf öğrencilerinin konuşma becerilerinin geliştirilmesi. Erzincan Üniversitesi Eğitim Fakültesi Dergisi, 19(1), 33-47.

Kurudayığlu, M. (2003). Konuşma eğitimi ve konuşma becerisini geliştirmeye yönelik etkinlikler. Türk Bilimi Araştırmalarl(13), 287-309. 
Miles, M, B. ve Huberman, A. M. (1994). Qualitative data analysis: An expanded Sourcebook. (2nd ed). Thousand Oaks, CA: Sage.

Nygaard, L. C., Herold, D. S. ve Namy, L. L. (2009). The semantics of prosody: Acoustic and perceptual evidence of prosodic correlates to word meaning. Cognitive Science, 33(1), 127-146.

Özden, M. (2018). Türkçe eğitimi lisans öğrencilerinin hazırlıklı ve hazırlıksız konuşma hakkında geliştirdikleri meteforlar. Ordu Üniversitesi Sosyal Bilimler Araştırmaları Dergisi, 8(2), 347-357.

Patton, M.Q. (2002). Qualitative research and evaluation methods (3rd Ed.). London: Sage Publications, Inc.

Sağlam, Ö. ve Doğan, Y. (2013). 7. sınıf öğrencilerinin hazırlıksız konuşma becerileri. Mustafa Kemal Üniversitesi Sosyal Bilimler Enstitüsü Dergisi, 10(24), 43-56.

Samuelsson, C., Scocco, C. ve Nettelbladt, U. (2003). Towards assessment of prosodic abilities in swedish children with language impairment. Logopedics Phoniatrics Vocology, 28(4), 156-166.

Schreiber, P. A. (1980). On the acquisition of reading fluency. Journal of Reading Behavior, (12), 177-186.

Schreiber, P. A. (1991). Understanding prosody's role in reading acquisition. Theory Into Practice, (30), 158164.

Şahin, M. (2011). Masalların çocuk gelişimine etkilerinin öğretmen görüşleri açısından incelenmesi. Millî Folklor, (89), 208-219.

Şimşek, A. (2004). İlköğretim okulu sosyla bilgiler dersi tarih konularının öğretiminde hikaye anlatım yönteminin etkililiği. Türk Ë̆itim Bilimleri Dergisi, 2(4), 495-509.

Temizkan, M. (2009). Akran değerlendirmenin konuşma becerisinin geliştirmesi üzerindeki etkisi. Mustafa Kemal Üniversitesi Sosyal Bilimler Enstitüsü Dergisi, 6(12), 90-112.

Temizyürek, F. (2007). İlköğretim ikinci kademede konuşma becerisinin geliştirilmesi. Ankara Üniversitesi Ĕgitim Bilimleri Fakültesi Dergisi, 40(2), 113-131.

Yalçın, A. ve Aytaş, G. (2003). Çocuk edebiyatı. Ankara: Akçă̆ Yayınları.

\section{Ekler}

Ek 1. Bay Ka Buk ve Ejder kitabı örnek etkinlik planı

Hazırlık Çalışmaları

Masal anlatımına geçiş aşaması

\section{Masal anlatımı sonrası konuşmaya yönelik çalışmalar}

Bu aşamada sınıf fiziksel ortamı masal anlatımına uygun hale getirilmek için düzenlenmiştir. İlk olarak oturma düzeni değiştirilerek hilal oturma düzenine geçilmiştir. Ardında bu hilalin içersine öğrenciler toplanarak ısınma çalışması gerçekleştirilmiştir.

Peritextual okumaya başlayarak kitap tanıtılmış, kitabın kapağında bulunan resimler, ön iç kapak ve arka iç kapakta bulunan peritextual ögeler, kitabın künyesi hakkında konuşmuştur. Öğrencilerin kitabın içeriği hakkında görüşleri alındıktan sonra kitap masallaştırılarak anlatılıışır.

Anlatımın ardından kitap içerisinde tekrar eden hayal kavramına vurgu yapılarak öğrencilerden "arkama yaslandım ve hayal kurdum benim hayalim..." cümlesiyle başlayıp hallerini anlatmları istenmiştir. Masal anlatımı ve etkinlikler tamamlandıktan sonra öğrencilerin masal ve etkinlere yönelik eleştirileri dinlenmiştir. 